\title{
Integration of Desired Learning Outcomes in a First Year Design Course
}

\author{
Marjan Eggermont and William (Bill) Rosehart \\ Schulich School of Engineering, University of Calgary \\ rosehart@ucalgary.ca, meggermo@ucalgary.ca
}

\begin{abstract}
Our first year design and communication course is an interdisciplinary course involving the application of engineering principles, design, communications, leadership and project management concepts through a sequence of team-based design projects. Integrating and translating these components from lectures to labs and vice versa is a challenge. During the upcoming Fall semester a paper project will be introduced that combines all communications deliverables into a submission for a student design challenge. The instructors expect a greater appreciation for the communications components as a part of the design course.
\end{abstract}

Keywords: Engineering design, communication, integration, paper project, student design challenge.

\section{INTRODUCTION}

The paper addresses the critical need to fully integrate most, if not all, learning outcomes in a first year design course. As background, in fall 2009 the Schulich School of Engineering adopted a first year design course based on a theoretical introduction to design and communications in a lecture environment, followed by hands on experiences in a workshop/design project environment. While the course was deemed largely successful, it was felt there was a partial disconnect between the material given in the lectures and the skills and knowledge required for the communications workshops and projects.

\section{PAST EXPERIENCE}

\subsection{Lecture component modifications}

For the fall 2011 offering of the course, the lecture component of the course was revised to increase the linkages between the lectures and the projects. This was partly done by replacing more theoretical project management material with more practical hands on techniques that can be applied to student's projects (Fig. 1). Without being able to reference quantitative studies, the teaching team also found that lectures that focused on presenting foundational material were not very effective compared to lectures that integrated case studies or discussions of projects the students where completing (Fig. 2).

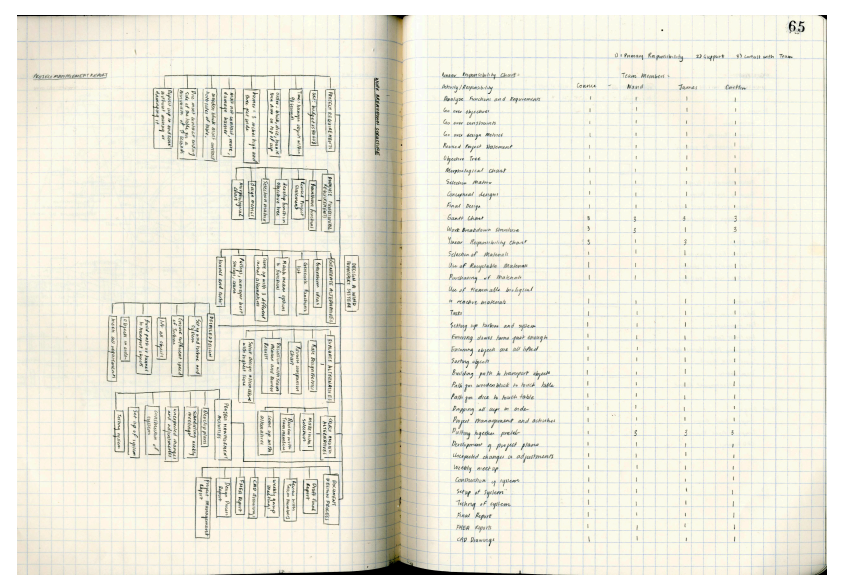

Fig. 1. Work breakdown structure as taught in lecture and applied in lab.

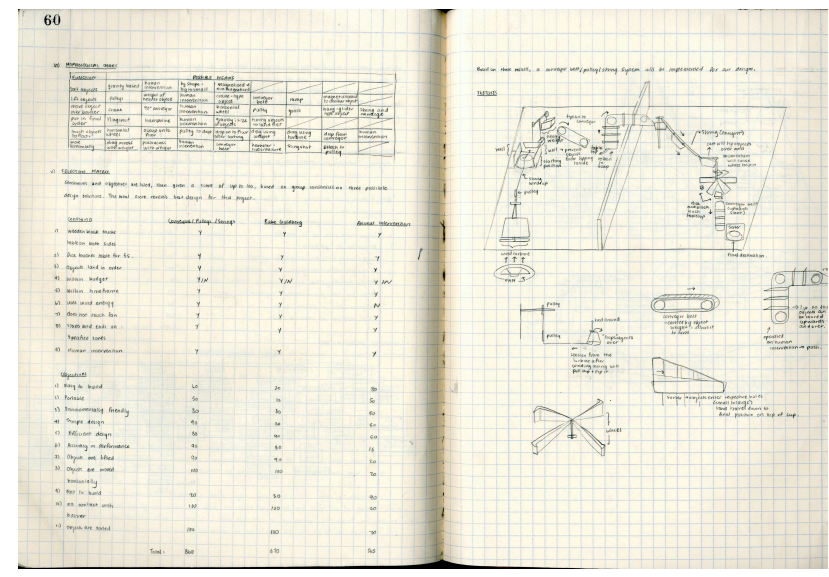

Fig. 2. Morphological chart and selection matrix as taught in lecture and applied in lab. 


\subsection{Integration using a paper project}

With respect to integration and impact of the communications component of the course, a revamping of the communications content is proposed for the fall of 2012. Students were taught communications components in the past, but often these were seen as 'make work' assignments. The instructors did see many positive outcomes: an increase in sketching in the logbooks (Fig. 5 ) and the use of concept sketches during meetings (Figs. 3 and 4)

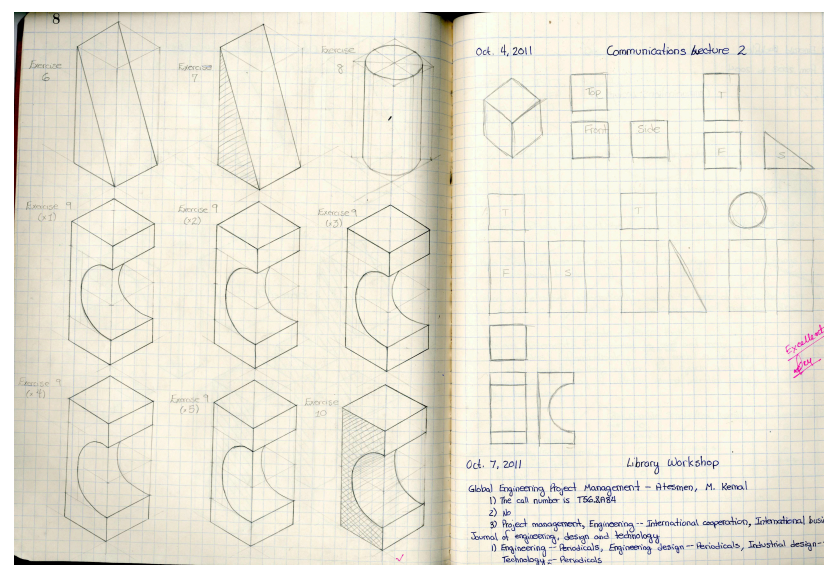

Fig. 3. Sketching practice.

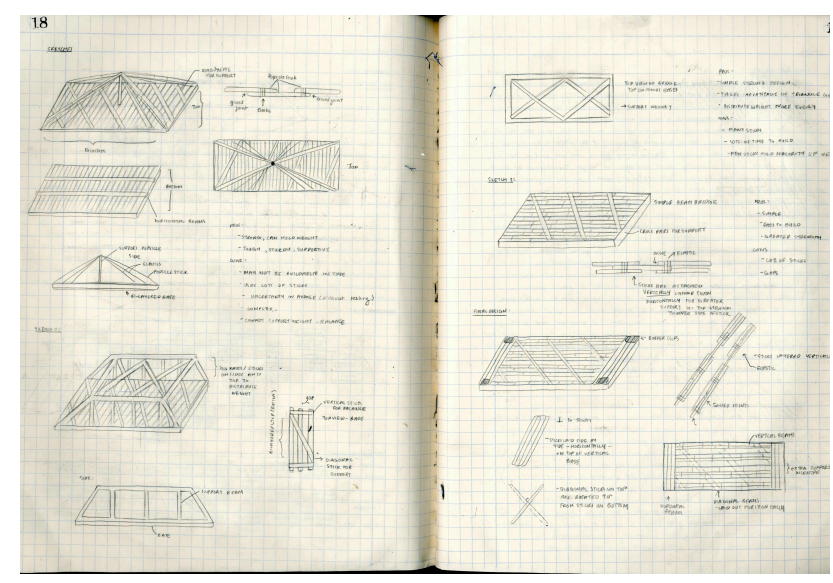

Fig. 4. Concept sketches.

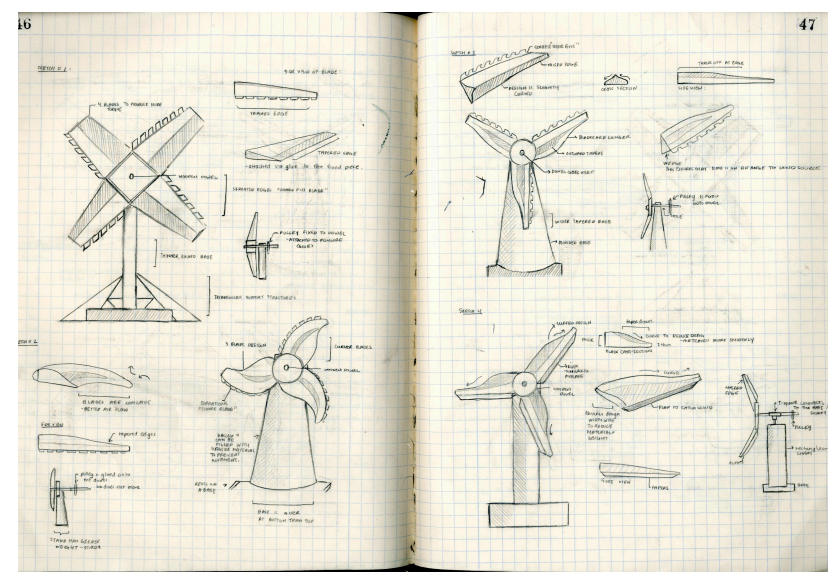

Fig. 5. Concept sketches and development.

A paper project based on a broad real world student design challenge will take the place of separate communications portfolio components. The project will follow the design process 'via' communications deliverables, in our case: concept sketches, technical writing components (from grammar practice to various stages of report writing), CAD modeling, oral presentations, a final report and a slide presentation (Fig. 6). These components are also required for the competition. By modeling an entire design communication process, we expect the communications components will be seen as integral to engineering design.

\section{CONCLUSION}

Communications is vital to any engineering design process. Students in the fall of 2012 will work towards a student design challenge as they fulfill their communications requirements in our course. We expect that participation in this real world challenge will encourage and excite the students while completing this integral part of the course.

\section{Acknowledgements}

We would like to acknowledge the students who allowed us to show their logbook pages. 
Engg 200 Fall 2012: Paper project plan

\begin{tabular}{|c|c|c|c|c|}
\hline Week & Comms Lecture & Workshop/Lab & Due & $\begin{array}{l}\text { Learning } \\
\text { Outcomes }\end{array}$ \\
\hline $\begin{array}{l}\text { 4-- } \\
\text { Oct. } 1\end{array}$ & $\begin{array}{l}\text { Communications \#2 } \\
\text { - Sketching } \\
\text { practice } \\
\text { - Writing in } \\
\text { - Engineering } \\
\text { - In-class writing } \\
\text { exercise } \\
\text { - Sust. workshop } \\
\text { - [LP \#2] }\end{array}$ & & & 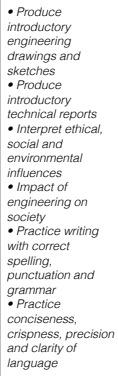 \\
\hline $\begin{array}{l}5-- \\
\text { Oct. } 8\end{array}$ & $\begin{array}{l}\text { Communications \#3 } \\
\text { - Sketching } \\
\text { practice } \\
\text { - Biomimicry case } \\
\text { studies } \\
\text { - Sust. workshop } \\
\text { - Oral } \\
\text { presentations } \\
\text { - Slide Design } \\
\text { - [LP \#3] }\end{array}$ & & & $\begin{array}{l}\text { - Produce } \\
\text { introductory } \\
\text { engineering } \\
\text { drawings and } \\
\text { sketches } \\
\text { - Produce } \\
\text { introductory } \\
\text { technical reports } \\
\text { - Intererret ethical, } \\
\text { social and } \\
\text { environmental } \\
\text { influences } \\
\text { - mpact of } \\
\text { engineering on } \\
\text { society }\end{array}$ \\
\hline
\end{tabular}

[...]" enrichment material

Engg 200 Fall 2012: Paper project plan

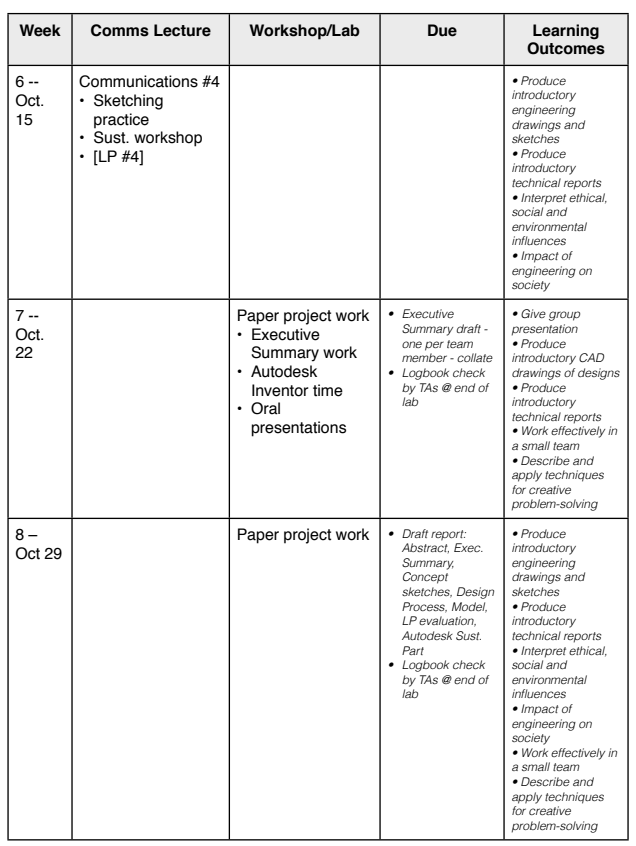

[...]' enrichment material
Engg 200 Fall 2012: Paper project plan

\begin{tabular}{|c|c|c|c|c|}
\hline Week & Comms Lecture & Workshop/Lab & Due & $\begin{array}{l}\text { Learning } \\
\text { Outcomes }\end{array}$ \\
\hline $\begin{array}{l}1- \\
\text { Sept. } \\
10\end{array}$ & & $\begin{array}{l}\text { 3 hours: } \\
\text { "Icebreaker" } \\
\text { 1. An introduction } \\
\text { to the } \\
\text { communications } \\
\text { component of the } \\
\text { course } \\
\text { 2. An introduction } \\
\text { to logbooks } \\
\text { 3. An introduction } \\
\text { to technical } \\
\text { communication. } \\
\text { This introduction is } \\
\text { similar to reverse } \\
\text { engineering. } \\
\text { Students are } \\
\text { asked to analyze a } \\
\text { document } \\
\text { 4. An introduction } \\
\text { to graphics in this } \\
\text { course }\end{array}$ & $\begin{array}{l}\text { Logbook check by } \\
\text { TAs at end of lab } \\
\text { [Participation mark. } \\
\text { in lab] }\end{array}$ & $\begin{array}{l}\text { - Individual and } \\
\text { team work } \\
\text { - Produce } \\
\text { introductory } \\
\text { engineering } \\
\text { drawings and } \\
\text { sketches } \\
\text { - Impact of } \\
\text { engineering on } \\
\text { societry } \\
\text { - Construct logical } \\
\text { and persuasive } \\
\text { argumments }\end{array}$ \\
\hline $\begin{array}{l}2-- \\
\text { Sept. } \\
17\end{array}$ & \begin{tabular}{|l} 
Communications \#1 \\
- Introduction to \\
paper project \& \\
components \\
- Introduction to \\
Biomimicry \\
Design Process \\
: [LP \#1 $]^{*}$ \\
- Sketching \\
practice \\
- Sust. workshop
\end{tabular} & & & 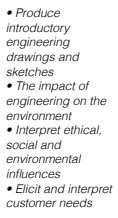 \\
\hline $\begin{array}{l}3-- \\
\text { Sept. } \\
24\end{array}$ & & $\begin{array}{l}1 \text { hour comms } \\
\text { portion: } \\
\text { Introduction to } \\
\text { sketching } 2 \\
\text { Introduction to } \\
\text { Inventor }\end{array}$ & $\begin{array}{l}\text { Logbook check by } \\
\text { TAs @ end of lab } \\
\text { [- in lab] }\end{array}$ & $\begin{array}{l}\text { - Produce } \\
\text { introductory } \\
\text { engineering } \\
\text { dravings and } \\
\text { sketches } \\
\text { introduce } \\
\text { introductory CAD } \\
\text { drawings of designs }\end{array}$ \\
\hline
\end{tabular}

[....]" enrichment material

Engg 200 Fall 2012: Paper project plan

\begin{tabular}{|c|c|c|c|c|}
\hline Week & Comms Lecture & Workshop/Lab & Due & $\begin{array}{l}\text { Learning } \\
\text { Outcomes }\end{array}$ \\
\hline $\begin{array}{l}9- \\
\text { Nov. } 5\end{array}$ & $\begin{array}{l}\text { Communication \#5 } \\
\text { - Sketching } \\
\text { - practice } \\
\text { - Report writing } 1\end{array}$ & & 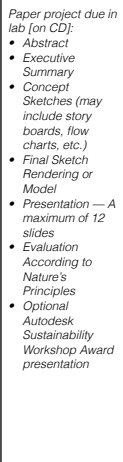 & 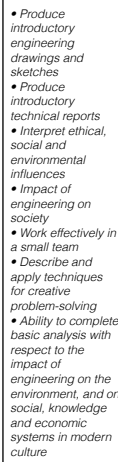 \\
\hline \multicolumn{5}{|l|}{\begin{tabular}{|l|}
$10--$ \\
Nov. \\
12 \\
\end{tabular}} \\
\hline $\begin{array}{l}11- \\
\text { Nov. } \\
19\end{array}$ & $\begin{array}{l}\text { Communication \#6 } \\
\text { - Sketching } \\
\text { practice } \\
\text { - Report writing } 2\end{array}$ & & & \begin{tabular}{|l|} 
- Produce \\
introductory \\
engineering \\
drawing and \\
sketches an
\end{tabular} \\
\hline & & & & \\
\hline
\end{tabular}

[...]" enrichment material

Fig. 6. Fall 2012 paper project plan. 